\title{
Prenatal Care and Prematurity
}

\author{
SAMUEL SHWARTZ, M.D., and JOHN H. VINYARD, Jr., M.P.H.
}

\begin{abstract}
A SIGNIFICANT association between prenatal care and prematurity has been reported by a number of investigators, but the exact nature of this association has not been definitely established. Recently, however, a useful methodology has been described for the valid measurement of associations between prenatal care and other factors in the course and outcome of pregnancy (1).

Women who receive early prenatal care appear to have a lower incidence of prematurity than women who receive late care or no prenatal care, and some investigators believe that this lowered incidence results directly from some beneficial influence of prenatal care. To obtain objective evidence for this belief, we undertook an analysis of this association in relation to certain other pregnancy variables: race, complications directly or indirectly related to pregnancy, gestation age, income level, maternal age, and parity.
\end{abstract}

\section{Material and Methods}

The data for this study were derived from information reported on certificates of live birth in the District of Columbia during 1960. A copy of the medical supplement to this certificate is shown on page 242 . Single and plural

Dr. Shwartz is chief of the bureau of maternal and child health and Mr. Vinyard was formerly chief of the biostatistics division, District of Columbia Department of Public Health. Mr. Vinyard is now special assistant to the director for research and experimental statistics, Medical Statistics Agency, Office of the Surgeon General, Department of the Army. This paper was presented in part at the 1962 meeting of the American Public Health Association at Miami, Fla. births from both operative and nonoperative deliveries are included in the birth cohort under investigation.

The information required for this study (exclusive of maternal age and parity) was completely reported for 18,112 (93.6 percent) of the 19,346 white live births and for 12,350 (86.9 percent) of the 14,213 nonwhite live births in 1960. The reliability of this information, compared with hospital record information, is generally good and has been described in part elsewhere (2). Data presented in the reference show a symmetrical distribution curve for gestation age, with the range and shape expected in a population of this size. While this does not imply a high degree of accuracy in reporting individual gestation ages, it does imply that errors in understating gestation age are balanced by errors in overstating gestation age.

The tabular construction employed for the cohort analyses (table 1) has been previously described (1). The construction is that of a modified life table adapted to the span of gestation. The span of gestation is divided into three gestation intervals: under 28 weeks, 28 through 35 weeks, and 36 weeks and over. Each gestation interval is treated as an independent experience. The women who are still pregnant at the beginning of each gestation interval constitute the population base for the calculation of certain rates.

Gestation age is measured from the first day of the last menstrual period. A certain degree of error in these measurements is unavoidable because of women who, after they have become pregnant, have some uterine bleeding which is mistaken for a menstrual period. There are, of course, other sources of error in the reporting of this information.

The levels of prenatal care are specific for 
each gestation interval. In the gestation interval under 28 weeks, the levels consist of $(a)$ onset of care during this interval (early care) and (b) no care during this interval. In the gestation interval 28 through 35 weeks the levels consist of $(a)$ onset of care in the interval under 28 weeks, (b) no care during the interval under 28 weeks but onset of care in the interval 28 through 35 weeks (late care), and (c) no care during the interval under 28 weeks as well as no care during the interval 28 through 35 weeks. Onset of care in the gestation interval 36 weeks and over is referred to as very late care.

The women who start care in a given interval do so at different stages of the interval. Hence, the correct population base for the calculation of rates is the total number of women-weeks of care in that gestation interval divided by the number of weeks in that gestation interval to give the equivalent number of women who re-

Table 1. Prenatal care and prematurity among women with complications directly related to pregnancy, by gestation age and race

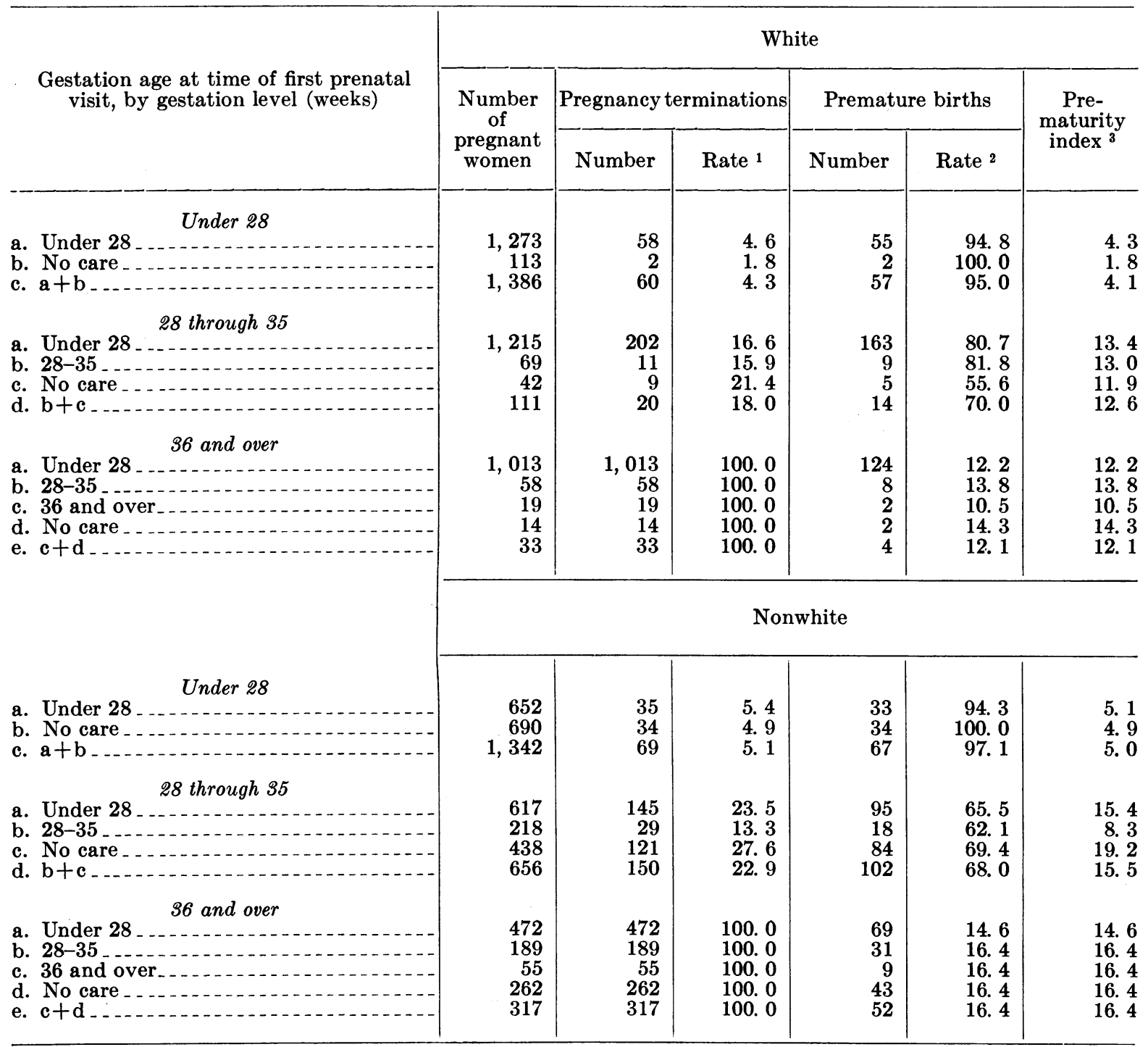

1 Live births per 100 pregnant women.

2 Premature live births per 100 live births.

3 Premature births per 100 pregnant women or product lof pregnancy termination rate and infant prematurity rate times 100 . 
ceive care from the beginning of the interval. The difference between this number and the actual number who start care in that interval belongs in the no-care group. To avoid this computation, the rates given in the tables for women who start care in a given gestation interval and for women who receive no care in the same gestation interval are approximations, calculated on the assumption that all women who start care in a given gestation interval do

Table 2. Prenatal care and prematurity among women with complications indirectly related to pregnancy, by gestation age and race

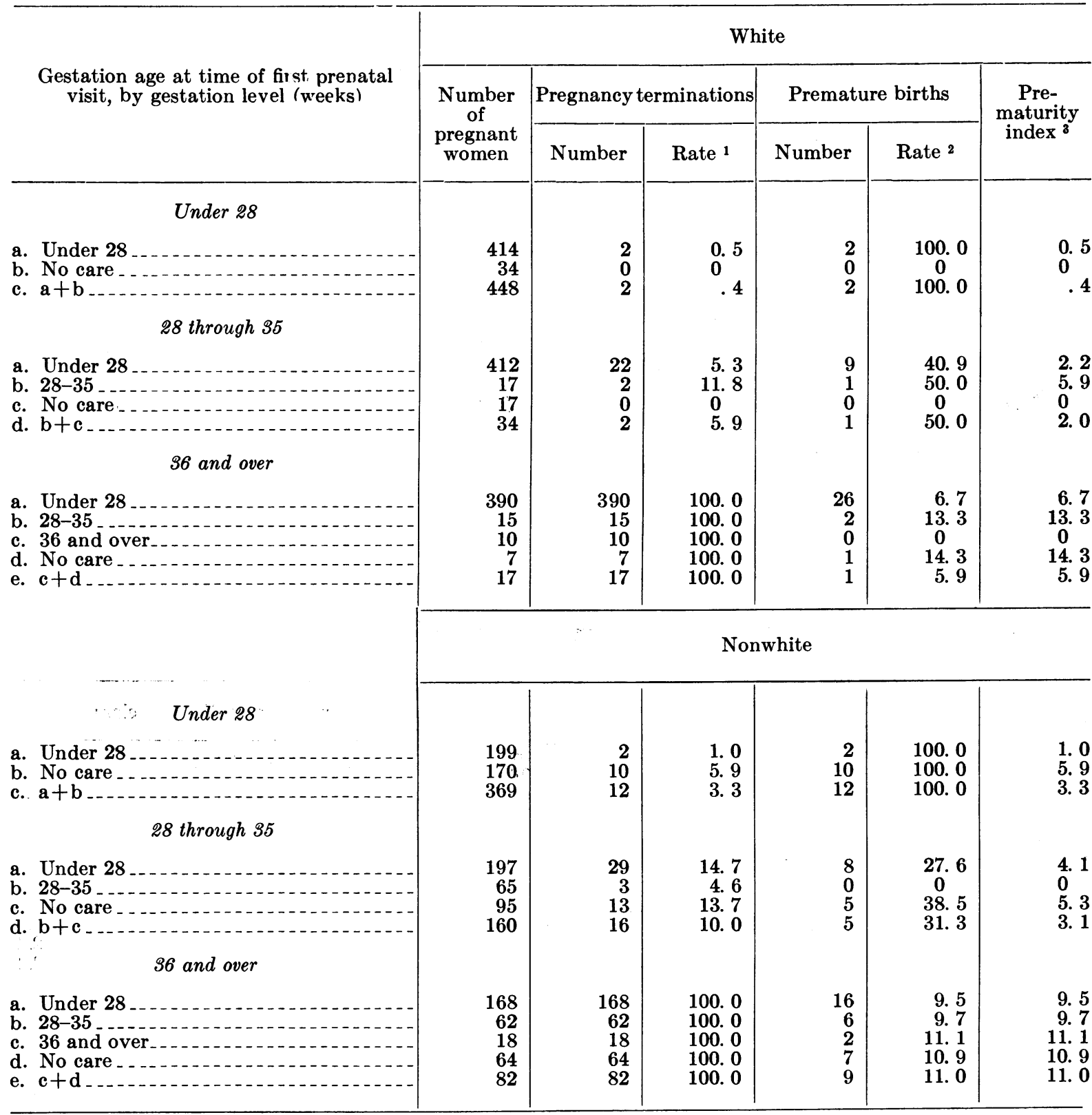

1 Live births per 100 pregnant women.

2 Premature live births per 100 live births.

3 Premature births per 100 pregnant women or product of pregnancy termination rate and infant prematurity rate times 100 . 
so at the beginning of the interval. For comparisons between groups and subgroups, the combined rates for women who start care in a given gestation interval and for women who receive no care in that interval are used, and these are correct rates.

The term "prematurity," as used in this study, means birthweight under 2,501 grams. Two methods are employed for measuring the incidence of premature births within a given gestation interval. One method, the prematurity rate, is the number of live births with birthweight under 2,501 grams per 100 live births. The other method, the prematurity index, is the number of live births with birthweight under 2,501 grams per 100 pregnant women. The prematurity index measures the combined effect of the pregnancy termination rate and the prematurity rate in a given gestation interval and is the product of these two rates (each over a denominator of 100) times 100.

\section{Findings}

Medical complications of pregnancy. Data on the association between prenatal care and prematurity among women with complications directly related to pregnancy are presented in table 1 and among women with complications indirectly related to pregnancy in table 2 . The conditions included in these two categories are listed in item 31 of the medical supplement.

In these tables the span of gestation is divided into three consecutive intervals, and the cohort of pregnant women is followed through each of these intervals. In each gestation interval the women who are still pregnant are classified into appropriate prenatal care levels. And for each level the tables show: $(a)$ the number of pregnancies that terminate in that gestation interval and the pregnancy termination rate, $(b)$ the number of these births that are premature and the prematurity rate, and (c) the number of pregnant women who have premature births and the rate, which we have termed the prematurity index. The prematurity index is a function of the product of the pregnancy termination rate and the prematurity rate. In the gestation interval 36 weeks and over the pregnancy termination rate is 100 percent and the prematurity index is identical with the prematurity rate.

Among women in each race with complications directly related to pregnancy (table 1) the pregnancy termination rate, the prematurity rate, and the prematurity index in each gestation interval are not significantly different in the different prenatal care levels. Likewise, among women in each race with complications indirectly related to pregnancy (table 2) the

\section{Table 3. Level of prenatal care and incidence of pregnancy complications, by gestation age and race}

\begin{tabular}{|c|c|c|c|c|c|}
\hline \multirow{3}{*}{ Gestation age at time of first visit (weeks) } & \multirow{3}{*}{$\begin{array}{c}\text { Pregnant } \\
\text { women }\end{array}$} & \multicolumn{4}{|c|}{ Pregnancy complication class } \\
\hline & & \multicolumn{2}{|c|}{ Directly related } & \multicolumn{2}{|c|}{ Indirectly related } \\
\hline & & Number & Percent & Number & Percent \\
\hline $\begin{array}{l}\text { Total } \\
\text { Under } 28 \\
\text { No care before } 28 \text { weeks. } \\
28-35 \\
\text { No care before } 36 \text { weeks. } \\
\text { 36 and over } \\
\text { No care before delivery }\end{array}$ & $\begin{array}{r}18,112 \\
16,840 \\
1,272 \\
779 \\
483 \\
230 \\
216\end{array}$ & $\begin{array}{r}1,386 \\
1,273 \\
113 \\
69 \\
42 \\
19 \\
14\end{array}$ & $\begin{array}{l}\text { 7. } 7 \\
\text { 7. } 6 \\
\text { 8. } 9 \\
\text { 8. } 9 \\
\text { 8. } 7 \\
\text { 8. } 3 \\
\text { 6. } 5\end{array}$ & $\begin{array}{r}448 \\
414 \\
34 \\
17 \\
17 \\
10 \\
7\end{array}$ & $\begin{array}{l}2.5 \\
2.5 \\
2.7 \\
2.2 \\
\text { 3. } 5 \\
\text { 4. } 3 \\
\text { 3. }\end{array}$ \\
\hline $\begin{array}{l}\text { Total } \\
\text { Under } 28 \\
\text { No care before } 28 \text { weeks. } \\
\text { 28-35 } \\
\text { No care before } \mathbf{3 6} \text { weeks. } \\
\text { 36 and over } \\
\text { No care before delivery }\end{array}$ & $\begin{array}{r}12,350 \\
6,239 \\
6,111 \\
2,257 \\
3,711 \\
631 \\
2,470\end{array}$ & $\begin{array}{r}1,342 \\
652 \\
690 \\
218 \\
438 \\
55 \\
262\end{array}$ & $\begin{array}{r}10.9 \\
10.5 \\
11.3 \\
9.7 \\
11.8 \\
8.7 \\
10.6\end{array}$ & $\begin{array}{r}369 \\
199 \\
170 \\
65 \\
95 \\
18 \\
64\end{array}$ & $\begin{array}{l}3.0 \\
3.2 \\
2.8 \\
2.9 \\
2.6 \\
2.9 \\
2.6\end{array}$ \\
\hline
\end{tabular}


pregnancy termination rate, the prematurity rate, and the prematurity index in each gestation interval are not significantly different in the different prenatal care levels.

The possibility of a significant association between the level of prenatal care and the incidence of pregnancy complications (and, there- by, of an indirect association between prenatal care and prematurity) is examined in table 3. Among the 18,112 white women in the study population, 16,840 started care in the gestation interval under 28 weeks and 1,272 received no care during this interval. The approximate incidence of direct complications at all stages of

Table 4. Prenatal care and prematurity among women with no complications of pregnancy, by gestation age and race

\begin{tabular}{|c|c|c|c|c|c|c|}
\hline \multirow{3}{*}{$\begin{array}{l}\text { Gestation age at time of first prenatal } \\
\text { visit, by gestation level (weeks) }\end{array}$} & \multicolumn{6}{|c|}{ White } \\
\hline & \multirow{2}{*}{$\begin{array}{l}\text { Number } \\
\text { of } \\
\text { pregnant } \\
\text { women }\end{array}$} & \multicolumn{2}{|c|}{ Pregnancy terminations } & \multicolumn{2}{|c|}{ Premature births } & \multirow{2}{*}{$\begin{array}{l}\text { Pre- } \\
\text { maturity } \\
\text { index } \\
{ }^{3}\end{array}$} \\
\hline & & Number & Rate ${ }^{1}$ & Number & Rate ${ }^{2}$ & \\
\hline Under 28 & & & & & & \\
\hline $\begin{array}{l}\text { a. Under } 28 \\
\text { b. No care } \\
\text { c. } \mathrm{a}+\mathrm{b}\end{array}$ & $\begin{array}{r}15,153 \\
1,125 \\
16,278\end{array}$ & $\begin{array}{r}44 \\
8 \\
52\end{array}$ & $\begin{array}{r}0.3 \\
.7 \\
.3\end{array}$ & $\begin{array}{r}31 \\
4 \\
35\end{array}$ & $\begin{array}{l}\text { 70. } 5 \\
50.0 \\
67.3\end{array}$ & $\begin{array}{r}0.2 \\
.4 \\
.2\end{array}$ \\
\hline 28 through 35 & & & & & & \\
\hline $\begin{array}{l}\text { a. Under } 28 \\
\text { b. } 28-35 \\
\text { c. No care } \\
\text { d. b+c }\end{array}$ & $\begin{array}{r}15,109 \\
693 \\
424 \\
1,117\end{array}$ & $\begin{array}{r}483 \\
26 \\
28 \\
54\end{array}$ & $\begin{array}{l}\text { 3. } 2 \\
\text { 3. } 8 \\
6.6 \\
4.8\end{array}$ & $\begin{array}{r}183 \\
6 \\
11 \\
17\end{array}$ & $\begin{array}{l}37.9 \\
23.1 \\
39.3 \\
31.5\end{array}$ & $\begin{array}{l}1.2 \\
2.9 \\
2.5 \\
1.5\end{array}$ \\
\hline 86 and over & & & & & & \\
\hline $\begin{array}{l}\text { a. Under } 28 \\
\text { b. } 28-35 \\
\text { c. } 36 \text { and over } \\
\text { d. No care } \\
\text { e. c+d }\end{array}$ & $\begin{array}{r}14,626 \\
667 \\
201 \\
195 \\
396\end{array}$ & $\begin{array}{r}14,626 \\
667 \\
201 \\
195 \\
396\end{array}$ & $\begin{array}{l}\text { 100. } 0 \\
100.0 \\
100.0 \\
100.0 \\
100.0\end{array}$ & $\begin{array}{r}554 \\
29 \\
19 \\
15 \\
34\end{array}$ & $\begin{array}{l}\text { 3. } 8 \\
\text { 4. } 3 \\
9.5 \\
7.7 \\
\text { 8. } 6\end{array}$ & $\begin{array}{l}\text { 3. } 8 \\
\text { 4. } 3 \\
9.5 \\
\text { 7. } 7 \\
\text { 8. } 6\end{array}$ \\
\hline & \multicolumn{6}{|c|}{ Nonwhite } \\
\hline Under 28 & & & & & & \\
\hline $\begin{array}{l}\text { a. Under } 28 \\
\text { b. No care } \\
\text { c. } \mathrm{a}+\mathrm{b}\end{array}$ & $\begin{array}{r}5,388 \\
5,251 \\
10,639\end{array}$ & $\begin{array}{r}66 \\
99 \\
165\end{array}$ & $\begin{array}{l}1.2 \\
1.9 \\
1.6\end{array}$ & $\begin{array}{r}40 \\
82 \\
122\end{array}$ & $\begin{array}{l}\text { 60. } 6 \\
82.8 \\
73.9\end{array}$ & $\begin{array}{l}0.7 \\
\text { 1. } 6 \\
\text { 1. } 1\end{array}$ \\
\hline 28 through 35 & & & & & & \\
\hline $\begin{array}{l}\text { a. Under } 28 \text {. } \\
\text { b. } 28-35 \\
\text { c. No care } \\
\text { d. b+c }\end{array}$ & $\begin{array}{l}5,322 \\
1,974 \\
3,178 \\
5,152\end{array}$ & $\begin{array}{l}509 \\
150 \\
476 \\
626\end{array}$ & $\begin{array}{r}9.6 \\
7.6 \\
15.0 \\
12.2\end{array}$ & $\begin{array}{r}196 \\
49 \\
214 \\
263\end{array}$ & $\begin{array}{l}\text { 38. } 5 \\
32.7 \\
45.0 \\
42.0\end{array}$ & $\begin{array}{l}\text { 3. } 7 \\
2.5 \\
6.7 \\
5.1\end{array}$ \\
\hline 36 and over & & & & & & \\
\hline $\begin{array}{l}\text { a. Under } 28 \\
\text { b. } 28-35 \\
\text { c. } 36 \text { and over } \\
\text { d. No care } \\
\text { e. c+d d }\end{array}$ & $\begin{array}{r}4,813 \\
1,824 \\
558 \\
2,144 \\
2,702\end{array}$ & $\begin{array}{r}4,813 \\
1,824 \\
558 \\
2,144 \\
2,702\end{array}$ & $\begin{array}{l}\text { 100. } 0 \\
100.0 \\
100.0 \\
100.0 \\
100.0\end{array}$ & $\begin{array}{r}311 \\
130 \\
31 \\
216 \\
247\end{array}$ & $\begin{aligned} \text { 6. } 5 \\
7.1 \\
\text { 5. } 6 \\
10.1 \\
9.1\end{aligned}$ & $\begin{aligned} \text { 6. } 5 \\
\text { 7. } 1 \\
\text { 5. } 6 \\
\text { 10. } 1 \\
9.1\end{aligned}$ \\
\hline
\end{tabular}

${ }^{1}$ Live births per 100 pregnant women. $\quad{ }^{2}$ Premature live births per 100 live births.

3 Premature births per 100 pregnant women or product of pregnancy termination rate and infant prematurity rate times 100 . 


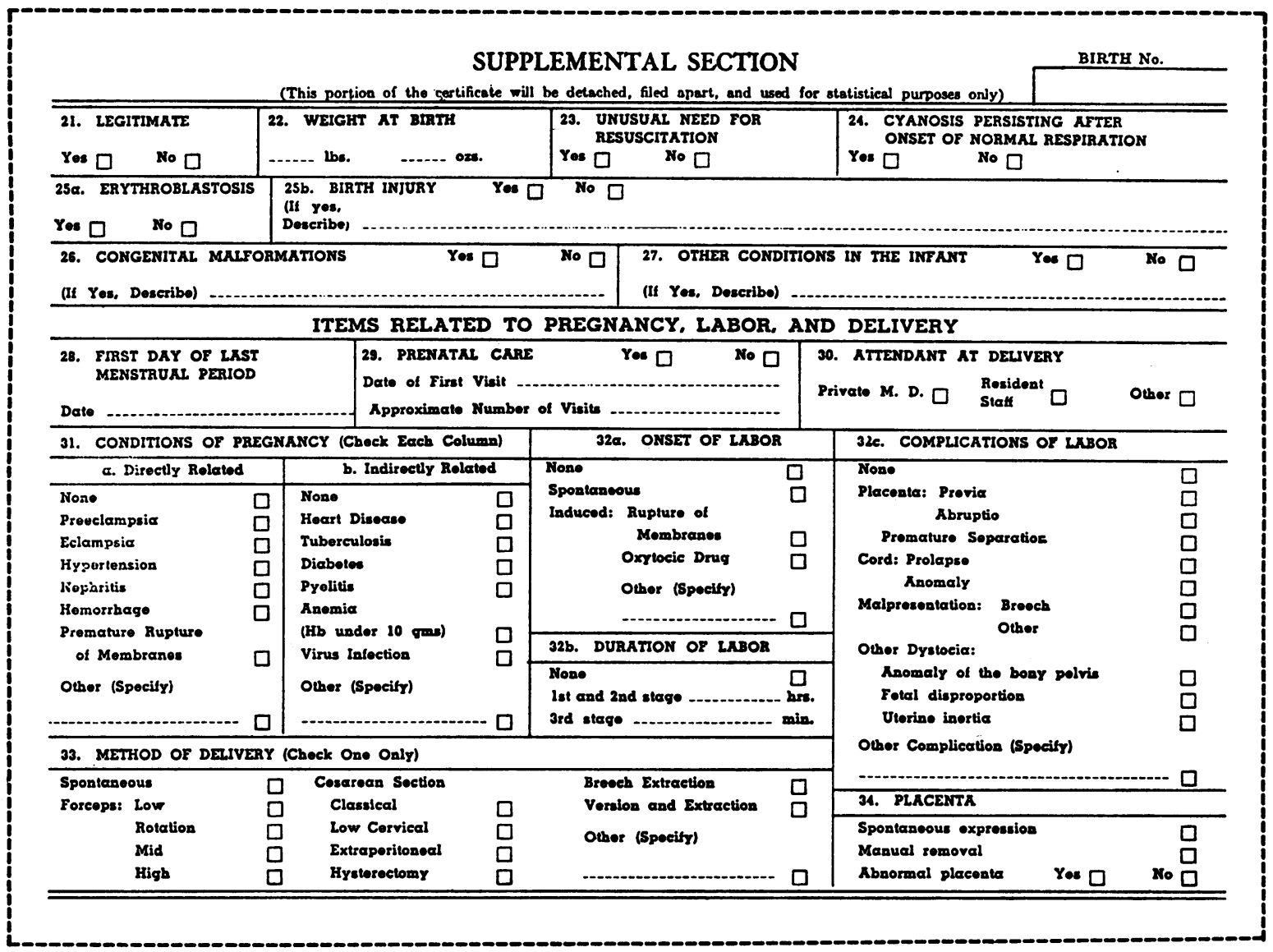

Table 5. Pregnancy terminations in the gestation interval 36 weeks and over in women with no pregnancy complication, by prenatal care level, gestation week at birth, and race

\begin{tabular}{|c|c|c|c|c|c|c|c|c|c|c|c|c|}
\hline \multirow{4}{*}{$\begin{array}{c}\text { Gestation } \\
\text { week at } \\
\text { birth }\end{array}$} & \multicolumn{6}{|c|}{ White } & \multicolumn{6}{|c|}{ Nonwhite } \\
\hline & \multicolumn{6}{|c|}{ Gestation week at first prenatal visit } & \multicolumn{6}{|c|}{ Gestation week at first prenatal visit } \\
\hline & \multicolumn{2}{|c|}{ Under 28} & \multicolumn{2}{|c|}{$28-35$} & \multicolumn{2}{|c|}{$\begin{array}{l}36 \text { and over or } \\
\text { no care }\end{array}$} & \multicolumn{2}{|c|}{ Under 28} & \multicolumn{2}{|c|}{$28-35$} & \multicolumn{2}{|c|}{$\begin{array}{l}36 \text { and over or } \\
\text { no care }\end{array}$} \\
\hline & $\underset{\text { ber }}{\text { Num- }}$ & $\begin{array}{l}\text { Per- } \\
\text { cent }\end{array}$ & $\underset{\text { ber }}{\text { Num- }}$ & $\begin{array}{l}\text { Per- } \\
\text { cent }\end{array}$ & $\underset{\text { ber }}{\text { Num- }}$ & $\begin{array}{l}\text { Per- } \\
\text { cent }\end{array}$ & $\underset{\text { ber }}{\text { Num- }}$ & $\begin{array}{l}\text { Per- } \\
\text { cent }\end{array}$ & $\underset{\text { ber }}{\text { Num- }}$ & $\begin{array}{l}\text { Per- } \\
\text { cent }\end{array}$ & $\underset{\text { ber }}{\text { Num- }}$ & $\begin{array}{l}\text { Per- } \\
\text { cent }\end{array}$ \\
\hline Total & 16,029 & 100. 0 & 740 & 100. 0 & 446 & 100.0 & 5,453 & 1.00. 0 & $\cdot 2075$ & 100.0 & 3,101 & 100. 0 \\
\hline $\begin{array}{l}36 \\
37 \\
38 \\
39 \\
40 \text { plus }\end{array}$ & $\begin{array}{r}471 \\
875 \\
1,763 \\
3,266 \\
9,654\end{array}$ & $\begin{array}{r}2.9 \\
5.5 \\
11.0 \\
20.4 \\
60.2\end{array}$ & $\begin{array}{r}23 \\
34 \\
82 \\
133 \\
468\end{array}$ & $\begin{array}{r}3.1 \\
4.6 \\
11.1 \\
18.0 \\
63.2\end{array}$ & $\begin{array}{r}15 \\
22 \\
38 \\
59 \\
312\end{array}$ & $\begin{array}{r}3.4 \\
4.9 \\
8.5 \\
13.2 \\
70.0\end{array}$ & $\begin{array}{r}306 \\
473 \\
812 \\
1,190 \\
2,672\end{array}$ & $\begin{array}{l}\text { 5. } 6 \\
8.7 \\
14.9 \\
21.8 \\
49.0\end{array}$ & $\begin{array}{r}113 \\
171 \\
270 \\
432 \\
1,089\end{array}$ & $\begin{array}{r}5.4 \\
8.2 \\
13.0 \\
20.8 \\
52.5\end{array}$ & $\begin{array}{r}194 \\
280 \\
401 \\
579 \\
1,647\end{array}$ & $\begin{array}{r}6.3 \\
9.0 \\
12.9 \\
18.7 \\
53.1\end{array}$ \\
\hline
\end{tabular}


gestation in the former, which is somewhat lower than the exact incidence, is 7.6 ; the approximate incidence of direct complications in the latter, which is somewhat higher than the exact incidence, is 8.9. The difference is not significant.
Among the 1,272 white women who received no care in the gestation interval under 28 weeks, 779 started care in the gestation interval 28 through 35 weeks and 483 continued in a nocare status. (The remainder had pregnancy terminations prior to this gestation interval.)

\section{Table 6. Prenatal care and prematurity among nonwhite women with no complications of preg- nancy, by gestation age and income level}

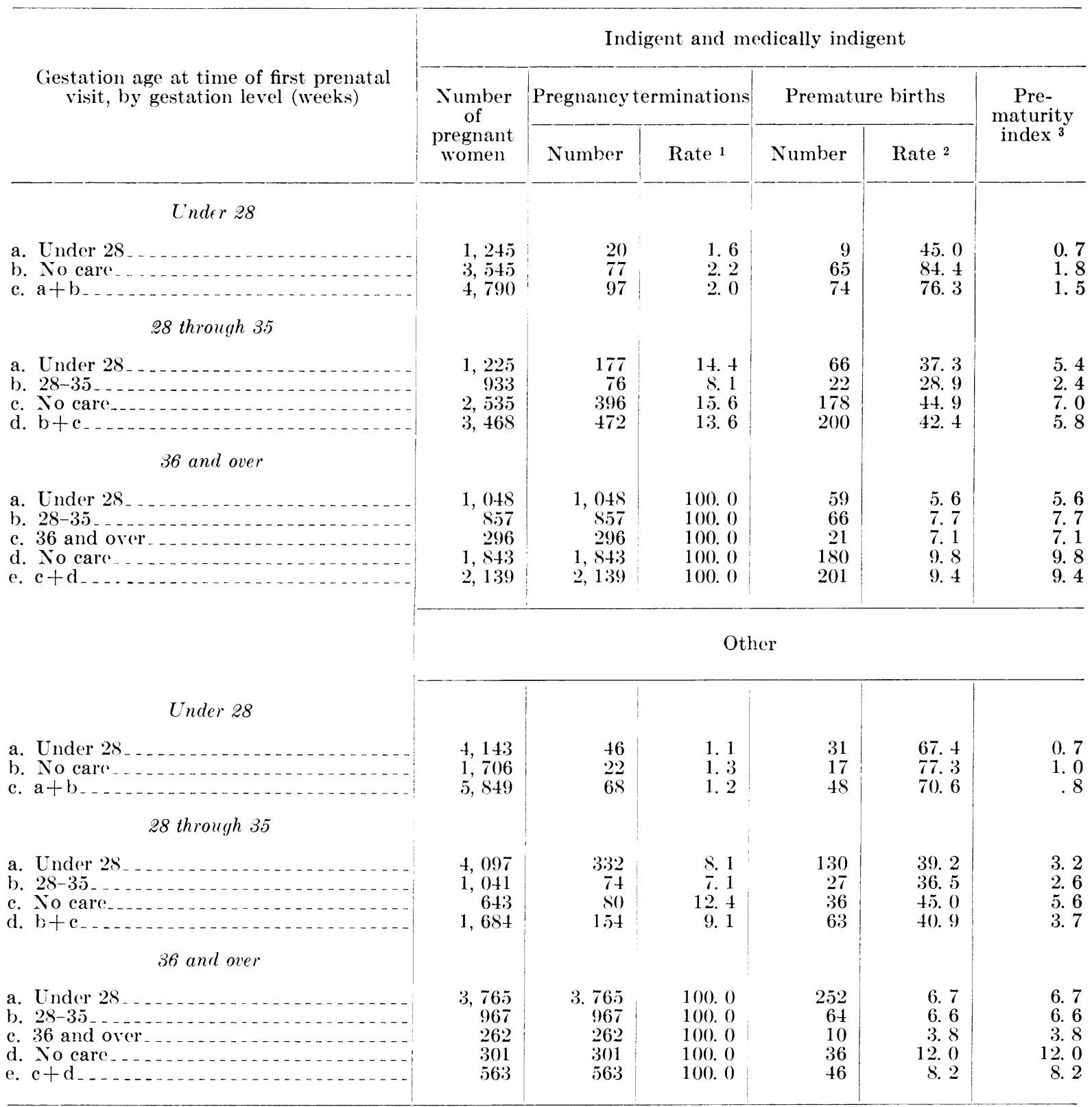

${ }^{1}$ Live births per 100 pregnant women. $\quad{ }_{2}^{2}$ Premature live births per 100 live births.

3 Premature births per 100 pregnant women or product of pregnancy termination rate and infant prematurity rate times 100 . 


\begin{tabular}{|c|c|c|c|c|c|c|}
\hline \multirow{4}{*}{$\begin{array}{c}\text { Gestation age at first prenatal } \\
\text { visit (weeks) }\end{array}$} & \multicolumn{6}{|c|}{ Maternal age in years } \\
\hline & \multicolumn{3}{|c|}{ All ages ${ }^{1}$} & \multicolumn{3}{|c|}{ Under 20} \\
\hline & \multirow{2}{*}{$\begin{array}{l}\text { Live } \\
\text { births }\end{array}$} & \multicolumn{2}{|c|}{ Premature births } & \multirow{2}{*}{$\begin{array}{l}\text { Live } \\
\text { births }\end{array}$} & \multicolumn{2}{|c|}{ Premature births } \\
\hline & & Number & Percent & & Number & Percent \\
\hline $\begin{array}{c}\text { White } \\
\text { Under } 28 \\
28-35 \\
36 \text { and over and no care }\end{array}$ & $\begin{array}{r}14,626 \\
667 \\
396\end{array}$ & $\begin{array}{r}554 \\
29 \\
34\end{array}$ & $\begin{array}{l}\text { 3. } 8 \\
\text { 4. } 3 \\
8.6\end{array}$ & $\begin{array}{r}1,048 \\
115 \\
85\end{array}$ & $\begin{array}{r}44 \\
4 \\
5\end{array}$ & $\begin{array}{l}\text { 4. } 2 \\
\text { 3. } 5 \\
\text { 5. } 9\end{array}$ \\
\hline $\begin{array}{l}\text { Nonwhite } \\
\text { Under } 28 \ldots+35 \\
28-36 \text { and over and no care } \\
36\end{array}$ & $\begin{array}{l}4,813 \\
1,824 \\
2,702\end{array}$ & $\begin{array}{l}311 \\
130 \\
247\end{array}$ & $\begin{array}{l}6.5 \\
7.1 \\
9.1\end{array}$ & $\begin{array}{l}776 \\
464 \\
598\end{array}$ & $\begin{array}{l}60 \\
39 \\
55\end{array}$ & $\begin{array}{l}\text { 7. } 7 \\
\text { 8. } 4 \\
9.2\end{array}$ \\
\hline
\end{tabular}

${ }^{1}$ Includes some "unknowns" not shown as a subtotal.

The approximate incidence of direct complications in the former is 8.9 and in the latter it is 8.7. Again the difference is not significant.

Among the 483 white women who were in a no-care status during the gestation interval under 36 weeks, 230 started care in the gestation interval 36 weeks and over and 216 continued in a no-care status. The approximate incidence of direct complications in the former is 8.3 and in the latter it is 6.5. The difference is not significant for the subject under investigation.

Similar findings (table 3) are noted among white women with indirect complications and among nonwhite women with direct or indirect complications.

As would be expected from the above data, women with uncomplicated pregnancies account for the observed association between prenatal care and prematurity (table 4). This finding is examined in greater detail later.

Based on these findings, three inferences appear warranted. First, the level of prenatal care does not significantly influence the incidence of medical complications of pregnancy or of the prematurity associated therewith. Second, the level of prenatal care does not significantly influence the incidence of early pregnancy termination among women with medical complications of pregnancy or the incidence of prematurity associated therewith. Since the incidence of medical complications of pregnancy and the incidence of prematurity associated therewith are expected to be influenced by the medical care component of prenatal care (as distinct from the nutritional or other components), and since the association between prenatal care and prematurity is found only in uncomplicated pregnancies, the third inference is that the strictly medical care component of prenatal care is not responsible for the observed association.

Length of gestation. The data in table 4 permit assessment of the association between prenatal care and prematurity at different lengths of gestation. In the gestation interval 28 through 35 weeks the pregnancy termination rate in each race is significantly higher in women with late and no care combined than in women with early care. The prematurity rate is not significantly different in the different prenatal care levels. Among whites the prematurity index is not significantly different in the different prenatal care levels. But in nonwhites the prematurity index is significantly higher in women with late and no care combined than in women with early care. In this gestation interval, then, the association between prenatal care and the prematurity index is a function of the pregnancy termination rate.

In the gestation interval 36 weeks and over (table 4), in each race the prematurity index is significantly higher in women with very late and no care combined than in women with earlier care. To determine whether this find- 
gestation age of 36 weeks and over, by race, maternal age, and prenatal care level

\begin{tabular}{|c|c|c|c|c|c|c|c|c|}
\hline \multicolumn{9}{|c|}{ Maternal age in years-Continued } \\
\hline \multicolumn{3}{|c|}{$20-29$} & \multicolumn{3}{|c|}{$30-39$} & \multicolumn{3}{|c|}{40 and over } \\
\hline \multirow{2}{*}{$\begin{array}{l}\text { Live } \\
\text { births }\end{array}$} & \multicolumn{2}{|c|}{ Premature births } & \multirow{2}{*}{$\begin{array}{c}\text { Live } \\
\text { births }\end{array}$} & \multicolumn{2}{|c|}{ Premature births } & \multirow{2}{*}{$\begin{array}{c}\text { Live } \\
\text { births }\end{array}$} & \multicolumn{2}{|c|}{ Premature births } \\
\hline & Number & Percent & & Number & Percent & & Number & Percent \\
\hline $\begin{array}{r}8,552 \\
374 \\
237\end{array}$ & $\begin{array}{r}308 \\
14 \\
19\end{array}$ & $\begin{array}{l}\text { 3. } 6 \\
\text { 3. } 7 \\
\text { 8. } 0\end{array}$ & $\begin{array}{r}4,602 \\
157 \\
70\end{array}$ & $\begin{array}{r}190 \\
8 \\
10\end{array}$ & $\begin{array}{r}4.1 \\
5.1 \\
14.3\end{array}$ & $\begin{array}{r}412 \\
19 \\
4\end{array}$ & $\begin{array}{r}12 \\
3 \\
0\end{array}$ & $\begin{array}{r}2.9 \\
15.8 \\
0\end{array}$ \\
\hline $\begin{array}{l}2,773 \\
1,036 \\
1,568\end{array}$ & $\begin{array}{r}157 \\
73 \\
144\end{array}$ & $\begin{array}{l}\text { 5. } 7 \\
\text { 7. } 0 \\
9.2\end{array}$ & $\begin{array}{r}1,175 \\
292 \\
500\end{array}$ & $\begin{array}{l}87 \\
16 \\
44\end{array}$ & $\begin{array}{l}7.4 \\
5.5 \\
8.8\end{array}$ & $\begin{array}{l}74 \\
26 \\
31\end{array}$ & $\begin{array}{l}6 \\
2 \\
4\end{array}$ & $\begin{array}{r}8.1 \\
7.7 \\
12.9\end{array}$ \\
\hline
\end{tabular}

ing is a function of the pregnancy termination rate, the data were tabulated in greater detail (table 5). These data show that the pregnancy termination rates in each race in each gestation week are not significantly different in the different prenatal care levels. In this gestation interval, then, the association between prenatal care and prematurity is a function of the prematurity rate and not of the pregnancy termination rate.

These findings indicate that there are two distinct components in the association between prenatal care and prematurity. One component is a function of the pregnancy termination rate in the gestation interval 28 through 35 weeks. The other component is a function of the prematurity rate in the gestation interval 36 weeks and over.

Income level. Income data are not available for the study population as a whole, but the nonwhites can be classified into two distinct income levels, based on their participation or lack of participation in the public medical care program for the indigent and medically indigent (delivery at D.C. General Hospital or delivery elsewhere). The number of whites who participated in this medical care program is too small for statistical analyses.

Table 6 presents data on the association between prenatal care and prematurity in these two income levels of nonwhite pregnant women with uncomplicated pregnancies. In the gestation interval 28 through 35 weeks within each income level the pregnancy termination rate, the prematurity rate, and the prematurity index are not significantly different in the different prenatal care levels. In the gestation interval 36 weeks and over within each income level the prematurity rate is significantly higher in women with very late and no care than in those with earlier care.

The association between prenatal care and prematurity in the gestation interval 36 weeks and over, therefore, is independent of the income level. Also, the association between prenatal care and prematurity in the gestation interval 28 through 35 weeks (table 4 ) is an indirect association mediated by the income level, because most women with late and no care are in the lower income class (table 6) and the pregnancy termination rate in this class is significantly higher than in the higher income class (table 6).

The findings thus far indicate that the association between prenatal care and prematurity that can still be considered a direct association is limited to infants of gestation age 36 weeks and over born to mothers with uncomplicated pregnancies.

Maternal age and parity. The effect of maternal age and parity on the association between prenatal care and prematurity was not included in the original study design. Hence, a few members of the study population, as previously defined, lack information on these items.

Data on the association between prenatal care 
Table 8. Live births and premature births in women with no pregnancy complication

\begin{tabular}{|c|c|c|c|c|c|c|}
\hline \multirow{4}{*}{$\begin{array}{l}\text { Gestation age at first prenatal } \\
\text { visit (weeks) }\end{array}$} & \multicolumn{6}{|c|}{ Parity } \\
\hline & \multicolumn{3}{|c|}{ All parities ${ }^{1}$} & \multicolumn{3}{|c|}{0} \\
\hline & \multirow{2}{*}{$\begin{array}{c}\text { Live } \\
\text { births }\end{array}$} & \multicolumn{2}{|c|}{ Premature births } & \multirow{2}{*}{$\begin{array}{c}\text { Live } \\
\text { births }\end{array}$} & \multicolumn{2}{|c|}{ Premature births } \\
\hline & & Number & Percent & & Number & Percent \\
\hline $\begin{array}{c}\text { White } \\
\text { Under } 28 \ldots-35_{2} \\
36 \text { and over and no care }\end{array}$ & $\begin{array}{r}14,626 \\
667 \\
396\end{array}$ & $\begin{array}{r}554 \\
29 \\
34\end{array}$ & $\begin{array}{l}3.8 \\
4.3 \\
8.6\end{array}$ & $\begin{array}{r}4,587 \\
266 \\
130\end{array}$ & $\begin{array}{r}178 \\
12 \\
14\end{array}$ & $\begin{array}{r}3.9 \\
4.5 \\
10.8\end{array}$ \\
\hline $\begin{array}{l}\text { Nonwhite } \\
\text { Under } 28 \\
28-35 \\
36 \text { and over and no care }\end{array}$ & $\begin{array}{l}4,813 \\
1,824 \\
2,702\end{array}$ & $\begin{array}{l}311 \\
130 \\
247\end{array}$ & $\begin{array}{l}6.5 \\
7.1 \\
9.1\end{array}$ & $\begin{array}{r}1,417 \\
420 \\
459\end{array}$ & $\begin{array}{r}121 \\
34 \\
48\end{array}$ & $\begin{array}{r}8.5 \\
8.1 \\
10.5\end{array}$ \\
\hline
\end{tabular}

1 Includes some "unknowns" not shown as a subtotal.

and prematurity in infants of 36 weeks' gestation and over born to women with uncomplicated pregnancies were cross-tabulated by maternal age, parity, and income level (nonwhites). The data are summarized for maternal age in table 7 and parity in table 8.

A significant association between prenatal care and prematurity was found in each race in each parity level within each age level and income level, except where the numbers of cases were too small for statistical analyses. It may be inferred, then, that the observed association between prenatal care and parity is independent of maternal age and parity.

\section{Discussion}

The purpose of this investigation was to seek evidence for a causal relation between prenatal care and prematurity. The evidence found for such a relation consists of $(a)$ the factual finding that there is a significant association between prenatal care and the component of prematurity which occurs in infants of 36 weeks' gestation and over born to women with uncomplicated pregnancies, $(b)$ the finding that this association is independent of maternal age, parity, income level, and race, and (c) a possible mechanism whereby prenatal care can influence birthweight. In the women with very late care or no prenatal care, the nutritional intake during pregnancy may well be inferior to that in women with earlier care, and may result in a higher incidence of inadequate fetal nutrition and a higher incidence of low-birthweight babies.

Unfortunately, in this study other findings seem to disprove a causal relation between prenatal care and prematurity: those that suggest that prenatal care is ineffective in the prevention of related pregnancy events, and those that suggest that the occurrence of prematurity may be independent of prenatal care.

The absence of a significant association between prenatal care and overall pregnancy complications (table 3) suggests that prenatal care has little or no part in the prevention of pregnancy complications. The absence of a significant association between prenatal care and early pregnancy termination (tables 1,2 , and 6 ) suggests that prenatal care has little or no part in the prevention of early pregnancy termination (prior to gestation week 36). Our related but unpublished studies on prenatal care and perinatal mortality fail to reveal a significant association between these two factors, a finding previously reported by Wells and associates (3), and this finding suggests that prenatal care plays little or no part in the prevention of fetal and neonatal mortality.

Data on premature births have been abstracted from tables 1, 2, and 4 and compiled in table 9 by race, gestation age, and pregnancy complication class. These data show the rela- 
and with gestation age of 36 weeks and over, by race, parity, and prenatal care level

\begin{tabular}{|c|c|c|c|c|c|c|c|c|}
\hline \multicolumn{9}{|c|}{ Parity-Continued } \\
\hline \multicolumn{3}{|c|}{1} & \multicolumn{3}{|c|}{2} & \multicolumn{3}{|c|}{3 and over } \\
\hline \multirow{2}{*}{$\begin{array}{l}\text { Live } \\
\text { births }\end{array}$} & \multicolumn{2}{|c|}{ Premature births } & \multirow{2}{*}{$\begin{array}{c}\text { Live } \\
\text { births }\end{array}$} & \multicolumn{2}{|c|}{ Premature births } & \multirow{2}{*}{$\begin{array}{c}\text { Live } \\
\text { births }\end{array}$} & \multicolumn{2}{|c|}{ Premature births } \\
\hline & Number & Percent & & Number & Percent & & Number & Percent \\
\hline $\begin{array}{r}4,079 \\
154 \\
89\end{array}$ & $\begin{array}{r}138 \\
6 \\
8\end{array}$ & $\begin{array}{l}\text { 3. } 4 \\
\text { 3. } 9 \\
9.0\end{array}$ & $\begin{array}{r}2,766 \\
101 \\
48\end{array}$ & $\begin{array}{r}122 \\
5 \\
5\end{array}$ & $\begin{array}{r}4.4 \\
5.0 \\
10.4\end{array}$ & $\begin{array}{r}3,194 \\
146 \\
128\end{array}$ & $\begin{array}{r}116 \\
6 \\
7\end{array}$ & $\begin{array}{l}\text { 3. } 6 \\
4.1 \\
\text { 5. } 5\end{array}$ \\
\hline $\begin{array}{r}104 \\
359 \\
516\end{array}$ & $\begin{array}{l}61 \\
29 \\
46\end{array}$ & $\begin{array}{l}\text { 5. } 5 \\
8.1 \\
8.9\end{array}$ & $\begin{array}{l}786 \\
324 \\
495\end{array}$ & $\begin{array}{l}45 \\
22 \\
42\end{array}$ & $\begin{array}{l}\text { 5. } 7 \\
6.8 \\
8.5\end{array}$ & $\begin{array}{r}1,499 \\
720 \\
1,225\end{array}$ & $\begin{array}{r}84 \\
45 \\
111\end{array}$ & $\begin{array}{l}5.6 \\
6.3 \\
9.1\end{array}$ \\
\hline
\end{tabular}

tive magnitude of the different subgroups of premature births.

The absence of a significant association between prenatal care and the component of prematurity associated with pregnancy complications (tables 1 and 2) suggests that prenatal care has little or no part in the prevention of this component of premature births. The absence of a significant association between prenatal care and the component of prematurity associated with early pregnancy termination (table 6) suggests that prenatal care plays little or no part in the prevention of this component of premature births. The prematurity rate (fetal weight distribution) in the gestation interval under 36 weeks in women with uncom- plicated pregnancies is not significantly different in each race or in each prenatal care level within each income class (tables 4 and 6), and this suggests that nutritional intake during pregnancy (prenatal care level) has little or no effect on fetal weight gain (fetal nutrition) up to gestation week 36 or thereabouts.

Assuming that prenatal care is indeed a direct determinant of only that component of prematurity which occurs in infants of 36 weeks' gestation and over born to women with uncomplicated pregnancies, we can calculate the probable effect of early prenatal care in these women on the overall incidence of premature births. If the prematurity rate in the gestation interval 36 weeks and over in white women with uncom-

Table 9. Premature births by race, gestation age, and pregnancy complication class

\begin{tabular}{|c|c|c|c|c|c|c|}
\hline \multirow{2}{*}{ Pregnancy complication class } & \multicolumn{3}{|c|}{ Number } & \multicolumn{3}{|c|}{ Percent } \\
\hline & Total & $\begin{array}{l}\text { Under } 36 \\
\text { weeks }\end{array}$ & $\begin{array}{l}36 \text { weeks } \\
\text { and over }\end{array}$ & Total & $\begin{array}{c}\text { Under } 36 \\
\text { weeks }\end{array}$ & $\begin{array}{l}36 \text { weeks } \\
\text { and over }\end{array}$ \\
\hline \multicolumn{7}{|l|}{ White } \\
\hline $\begin{array}{l}\text { Total } \\
\text { Complication } \\
\text { No complication }\end{array}$ & $\begin{array}{r}1,263 \\
411 \\
852\end{array}$ & $\begin{array}{l}481 \\
246 \\
235\end{array}$ & $\begin{array}{l}782 \\
165 \\
617\end{array}$ & $\begin{array}{r}100.0 \\
32.5 \\
67.5\end{array}$ & $\begin{array}{l}\text { 38. } 1 \\
\text { 19. } 5 \\
\text { 18. } 6\end{array}$ & $\begin{array}{l}61.9 \\
13.0 \\
48.9\end{array}$ \\
\hline Nonwhite & & & & & & \\
\hline $\begin{array}{l}\text { Total } \\
\text { Complication } \\
\text { No complication }\end{array}$ & $\begin{array}{r}1,741 \\
472 \\
1,269\end{array}$ & $\begin{array}{l}870 \\
289 \\
581\end{array}$ & $\begin{array}{l}871 \\
183 \\
688\end{array}$ & $\begin{aligned} 100.0 \\
27.1 \\
72.9\end{aligned}$ & $\begin{array}{l}\text { 50. } 0 \\
\text { 16. } 6 \\
\text { 33. } 4\end{array}$ & $\begin{array}{l}50.0 \\
10.5 \\
39.5\end{array}$ \\
\hline
\end{tabular}


plicated pregnancies and with very late or no prenatal care were reduced to the prematurity rate in similar women with early care (table 4), the reduction in the number of premature births would be about 16 or not more than 1.5 percent of the total white premature births. Likewise, if the prematurity rate in the gestation interval 36 weeks and over in nonwhite women with uncomplicated pregnancies and with very late or no prenatal care were reduced to the prematurity rate in similar women with early care (table 4), the reduction in the premature births would be about 60 , or not more than 4 percent of the total nonwhite premature births.

Thus, the question of a causal relation between prenatal care and prematurity is academic as far as this study population is concerned, and a definitive answer must await further study.

\section{Summary}

The association of prenatal care and prematurity among 18,112 white women and 12,350 nonwhite women with premature liveborn infants was analyzed in relation to maternal age, parity, race, income level (nonwhite only), ges- tation age at delivery, and medical complication class. The data were obtained from the $\mathbf{1 9 6 0}$ certificates of live births in the District of Columbia.

A significant association was found only in women with uncomplicated pregnancies who delivered in gestation week 36 and thereafter, and this association is independent of maternal age, parity, race, and income level. Whether the basis for this association is a causal relation between prenatal care and prematurity cannot be definitely determined from the available evidence. In any event, the presumed causal relation was shown to have a negligible effect on the overall incidence of prematurity in the study population.

\section{REFERENCES}

(1) Shwartz, S. : Prenatal care, prematurity, and neonatal mortality. Amer J Obstet Gynee 83: 591598 (1962).

(2) Shwartz, S., and West, H.: Potentialities and limitations of medical data on official birth certificates. Amer J Public Health 50: 338-345 (1960).

(3) Wells, H. B., Greenberg, B. G., and Donelly, J. F. : North Carolina fetal and neonatal death study. 1. Study design and some preliminary results. Amer J Public Health 48: 1583-1595 (1958).

\section{Salmonellosis Seminars}

A seminar service on salmonellosis control is offered by the Public Health Service through the Communicable Disease Center, Atlanta, Ga. The seminars provide information on new methods of investigation, laboratory procedures, collection and handling of specimens, and epidemic patterns, including hospital infections.

The service is available to State health associations that want to hold seminars on salmonellosis during their annual professional meetings. Seminars co-sponsored by the health association and the Communicable Disease Center are currently scheduled for the Kansas Public Health Association, April 22, 1965, Topeka; Indiana Public Health Association, April 29, 1965, Indianapolis; and Iowa Public Health Association, May 1965, Des Moines. 